\title{
Analysis of Pension Fund Investment Portfolio Diversification Policy and Its Impact on Financial Performance (Study on PLN Pension Fund 2010-2018)
}

\author{
Wiwik Utami Toharudin ${ }^{1}$ \\ ${ }^{1}$ Postgraduate Accounting Major, Universitas Mercu Buana, Jakarta, Indonesia \\ Correspondence: Wiwik Utami Toharudin, Postgraduate Accounting Major, Universitas Mercu Buana, Jakarta, \\ Indonesia.
}

Received: September 8, 2021

Accepted: September 27, $2021 \quad$ Online Published: September 30, 2021

doi:10.20849/ajsss.v6i3.935

URL: https://doi.org/10.20849/ajsss.v6i3.935

\begin{abstract}
In deciding to invest in a financial instrument in the money market or capital market, experience and sharpness of analysis are needed so that investors can maximize the obtain returns, for pension fund managers it is important to be able to develop the set of funds obtained from customers in order to provide maximum returns. and the available funds become more useful. This study aims to analyze the optimization of the diversification of pension fund investment portfolios policy and their impact on the financial performance of pension funds. This research was conducted on Employer Pension Fund (DPPK) PT. PLN (Persero) during the period of 2010-2018 using two analytical models, namely the Markowitz and Sharpe models, then the results of the two models were compared with the paired t-sample difference test and correlated with the Pearson correlation test. The calculation results conclude that the portfolio proportions of 6 types of investment instruments provide almost the same optimal results based on the two models and based on the proxies of the two models in analyzing portfolio optimalization on financial performance there is no significant difference with a result of 0.094. The Markowitz model with consideration of investors' preferences for risk has a strong correlation with one of the financial indicators, namely the Fund Adequacy Ratio (FAR) with a correlation value of 0.637 or $63.7 \%$.
\end{abstract}

Keywords: Markowitz, Sharpe, optimalization portfolio, financial performance

\section{Introduction}

Pension Fund is a form of fund raising conducted by the company as an alternative form of the company to ensure welfare for employees in retirement, this is because pension funds provide benefits for pension money by expanding the contributions given by participants. The form of pension fund development carried out by managers in a prudent, professional and productive manner by investing these funds into sectors that generate returns. In Indonesia, the regulations governing pension funds are contained in Law No. 11 of 1992.

The financial performance of pension funds can be analyzed from the extent to which the success of pension fund institutions is able to develop their portfolios, in general the purpose of portfolio performance is to determine portfolios that can provide added value by maximizing returns with a certain level of risk that is still acceptable. In the management of pension funds, there are three main foundations that serve as a reference in making investment decisions, namely the expected return, the level of risk, and the relationship between return (yield) and risk. According to the Association of Indonesian Pension Funds (ADPI) it was noted that the management of the largest pension funds is owned by BUMN (State Owned Enterprises).there are 10 government-owned DPPKs that have the largest funds, one of which is the PLN Pension Fund (DPPK-PLN) but it turns out that the management of the PLN Pension Fund is considered not optimal in allocating its asset investment, this is due to several things including:

a. Net assets as of December 31, 2018 were Rp. 9,167,139,340,885, which means an increase of $12.13 \%$ compared to net assets as of December 31, 2018 of Rp. 8,174,807,345,818.

b. The ROI (R) achievement was $8.38 \%$ above the DP-PPMP average of $8.28 \%$ and the average for all Pension Funds which was only $7.49 \%$. Achievement of ROI $(\mathrm{R}+\mathrm{U} 0$ of $5.93 \%$ above the average DP-Pmp which is $3.30 \%$ and the average of all DPs which is only $3.69 \%$. 
While on the other hand there are values that indicate negative developments, including:

a. Total investment (fair value) as of December 31, 2018 was IDR 7,999,043,241,060 which means a decrease of $(1.31 \%)$ compared to the total investment (fair value) as of December 31, 2017 of IDR $8,105,049,925,755$

b. The financial ratio of the PLN Pension Fund has decreased if the position is as of December 31, 2018 to the position as of December 31, 2017. The funding ratio (RKD) has decreased by $3.54 \%$, from $100.29 \%$ (2017) to $96.75 \%$ (2018). The investment ratio (ROI) decreased by $5.41 \%$ from $11.34 \%$ (2097) to $5.93 \%$ (2018). Asset ratio (ROA) decreased by 5.8\%m from 11.28\% (2017) to 5.48\% (2018). In addition, in 2018 the PLN DPPK funding ratio was below $100 \%$ and below the 2018 RKA/RI the decline in the funding ratio was caused by: due to the delay in receiving additional contributions and there are contribution receivables of more than 3 (three) months which are not included as wealth.

Theoretically, in an effort to maximize return on investment under a certain level of risk or minimize investment risk under a certain rate of return, various portfolio optimization models have been developed.

Among the models that can improve diversification optimization is the Markowitz model and Sharpe Index or Sharpe Ratio or Sharpe Model. The two portfolio optimization models have similarities because both models take into account two main factors, namely the return and risk factors in calculating the diversification of a portfolio's investment instruments. However, between the two models there are differences, according to Sinha and Tripathi (2017) this is in different parameters when building a portfolio.

The Markowitz model starts from historical data which is then analyzed to produce a description of portfolio performance whether it is included in the optimal group or vice versa Iwan et al (2017), besides that the Markowitz model requires more processes, namely as many as $[\mathrm{N}(\mathrm{N}+3) / 2]$ calculations. While the Sharpe method does not take into account the covariance between investment instruments. And instead the Sharpe Ratio uses information on the relationship between each stock and the market.

The purpose of this study is to describe how the calculation of the optimization of the pension fund portfolio at PT PLN with the Markowitz and Sharpe models and determine the most appropriate model, then find out if there are differences between the two models and the last is to look for the correlation of the Markowitz and Sharpe analysis models with financial performance measured by return on investment, return on assets and fund adequacy ratio

\section{Literature Review}

\subsection{Efficient Market Theory}

The efficient market hypothesis or efficient market is a theory put forward by Fama in 1965 that the capital market is said to be efficient if it fulfills a condition that describes that new information from the government of a country and the issuer or company concerned is widely distributed, fast, easy and obtained cheaply by market participants or investors. This EMH theory connect the existing information to the price of a stock.

\subsection{Markowitz Model}

Harry M. Markowitz in 1952 developed a model with a proposition that is quite popular to this day, namely "not to place all your eggs in one basket". Markowitz's proposition with the aim that to minimize investment risk, investors must diversify their investments, which means investors must invest in many securities (portfolios). This is intended so that investment risk is spread throughout the portfolio, and is not concentrated on one portfolio instrument (Sinha \& Tripathi, 2017). The Markowitz model is intended to select the optimal portfolio for risk averse investors. Markowitz shows that the value of a security can be evaluated by 1) the mean return, 2) the standard deviation (as risk), and 3) the correlation among other securities in the portfolio. Markowitz proposes that investors focus on selecting portfolios based on overall risk and return characteristics.

\subsection{Sharpe Model}

William Forsyth Sharpe, in 1963, proposed a portfolio selection model for the Sharpe Ratio (Sharpe Index, Sharpe measure, Reward to Variability Ratio). Sharpe assumes that the return from the security trend or the movement of the security return is the same as the movement of the market index (market index). The parallel movement of securities and market indices is measured by beta $(\beta)$. The calculation of the Sharpe Ratio is based on (1) Excess return or Alpha ( $\alpha$ ), and (2) Beta ( $\beta$ ). Sharpe's ratio is more suitable for a well-diversified portfolio, because it more accurately calculates portfolio risk (Sinha \& Tripathi, 2017) Sharpe (1995) states that risk and return are two characteristics of investment, so they are important factors that must be evaluated. The Sharpe Ratio evaluates a manager's portfolio based on 1) the rate of return and 2) diversification (i.e. considering the 
total portfolio risk as measured by the standard deviation of the denominator). The optimal portfolio is the portfolio that investors choose from the many choices available in an efficient portfolio pool. According to Nur Sarva and Pardomuan (2019), the assumption attached to an efficient portfolio is that all investors do not like risk. A portfolio is categorized as efficient if it has the same level of risk, or provides a higher level of profit or is able to generate the same level of profit, but with a lower risk (Tandellin, 2001). The optimal portfolio is pursued by all pension fund institutions, including DPPK-PLN. DPPK-PLN has also implemented a diversification policy to obtain an optimal portfolio.

\subsection{Financial Performance Pension Fund}

There are three important financial indicators as material for analysis in this study, namely Return On Investment (ROI), Return on Assets (ROA) and Fund Adequacy Ratio (FAR/RKD).

1. ROI (Return on Investment)

Return on investment is measured by the following formula:

$$
R O I=\frac{\text { Net Investment Return }}{\text { Net Average Investment }}
$$

2. ROA (Return on Asset)

$$
R O A=\underline{\text { Income After Tax }}
$$

3. FAR (Fund Aduquacy Ratio)

$$
F A R=\frac{\text { Total Net Asset }}{\text { Actuarial Obligations }}
$$

In this study, analysis of the optimal diversification calculation of the Markowitz model with Sharpe's ratio was carried out. First of all, the model will first be calculated separately (partial), and each calculation method will be analyzed to assess the optimization of the pension fund portfolio performance.

PLN Employer Pension Funds (DPPK-PLN)

$\downarrow$

Purpose of Portfolio Diversification Policy Analysis

1. To find out the performance of diversification of DPPK - PLN investment instruments for the period 2010-2018 with the Markowitz . model

2. To find out the performance of diversification of DPPK - PLN investment instruments for the period 2010-2018 with the Sharpe model

3. Differences in the optimum performance of the DPPK - PLN portfolio between the Markowitz model and the Sharpe model

4. Optimization model that has the strongest correlation with Return on Investment, Return On Assets and Fund Adequacy Ratio.

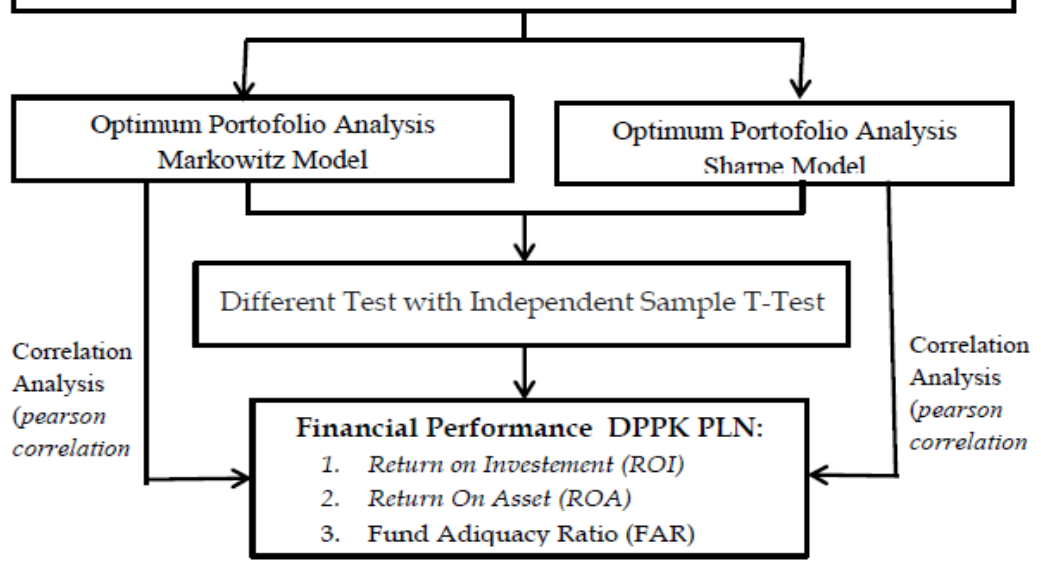

Figure 1. Conceptual frameworks 
Furthermore, the two methods will be compared using a different test, this comparison is needed so that it will be known whether there is a significant difference between portfolio performance analysis with the Markowitz method and the Sharpe method, then the next analysis carried out is to find the strongest correlation or relationship between the two methods with finance performance which is proxied by return on investment (ROI), return on assets (ROA) and fund adequacy ratio (FAR/RKD)

\section{Hypothesis Development}

Referring to the formulation of the problem, from the four research questions, there are two research questions that are analytic. Therefore, it is hypothesized in this study that only two research questions are analytic. The hypotheses of this research are:

Hypothesis 1: There is a difference in the results of measuring the performance of the PLN Pension Fund portfolio with the Markowitz method and the Sharpe method.

Hypothesis 2: Portfolio performance as measured by Return On Investment Return On Assets and Fund Adequacy Ratio has a stronger correlation when using the Markowitz method.

\section{Research Methods}

This research approach is a quantitative approach, because this research seeks to accurately measure something (Cooper and Schindler, 2014: 146). The type of research is ex post facto design (Cooper and Schindler, 2014: 127). This study was designed to answer descriptive questions, and questions about the relationship between variables. (Creswell \& Creswell, 2018: 207). This research method is a comparative descriptive study to determine the optimal portfolio performance using two different methods, namely Markowitz and Sharpe. Comparative research method is a research that compares the existence of a variable or more different samples (Sugiyono, 2013)

\section{Research Object, Population and Sample}

This research was conducted at PT. PLN (Persero) for 9 years. The general population is the entire financial data of DPPK-PLN since this institution was founded 54 years ago. The target population is DPPK-PLN financial data for the last 9 years (2010-2018) with monthly data frequency. The population accessed is DPPK-PLN financial data for the last 9 years (2010-2018). The sample in this study is the DPPK-PLN research variable data with an annual frequency, in the 2010-2018 period.

Table 1 presents the order of investment allocation portions for the average nine investment instruments (securities) for the 2010-2018 period.

Tab le 1

Instrumen t Proportion for period $2010 \quad-2018$ (in \% )

\begin{tabular}{|c|c|c|c|c|c|c|c|c|c|c|}
\hline Instrumen & 2010 & 2011 & 2012 & 2013 & 2014 & 2015 & 2016 & 2017 & 2018 & $\begin{array}{c}\text { Averag } \\
\text { e }\end{array}$ \\
\hline $\begin{array}{l}\text { Government } \\
\text { Securities (SBN) }\end{array}$ & 28,64 & 25,17 & $\begin{array}{r}24,0 \\
1 \\
\end{array}$ & 22,39 & 19,45 & 14,17 & 15,91 & 15,83 & 15,14 & 20,08 \\
\hline Deposit On Call & 0,40 & 0,45 & 0,41 & 0,87 & 0,82 & 1,30 & 0,83 & 0,80 & 1,31 & 0,80 \\
\hline Time Deposit & 8,21 & 7,62 & $\begin{array}{r}12,7 \\
6 \\
\end{array}$ & 10,06 & 7,48 & 10,71 & 6,84 & 7,42 & 3,89 & 8.33 \\
\hline Stock & 0,70 & 3,03 & 5,37 & 6,96 & 8,07 & 9,42 & 10,05 & 11,02 & 11,78 & 7,38 \\
\hline Bond & 38,25 & 33,77 & $\begin{array}{r}33,8 \\
7 \\
\end{array}$ & 36,16 & 35,95 & 36,54 & 37,70 & 34,43 & 35,88 & 35,76 \\
\hline Sukuk & 0,20 & 0,15 & 0,08 & 0,02 & 0,00 & 0,00 & 0,02 & 0,12 & 0,12 & 0,08 \\
\hline Mutual Fund & 14,09 & 20,81 & $\begin{array}{r}14,9 \\
2 \\
\end{array}$ & 13,70 & 15,59 & 14,53 & 13,83 & 12,85 & 12,15 & 14,72 \\
\hline Direct Placement & 0,53 & 0,59 & 0,72 & 1,40 & 1,90 & 2,30 & 3,61 & 6,74 & 8,57 & 2,93 \\
\hline $\begin{array}{l}\text { Land and } \\
\text { Building }\end{array}$ & 8,96 & 8,41 & 7,86 & 8,41 & 10,75 & 11,13 & 11,21 & 10,79 & 11,16 & 9,85 \\
\hline
\end{tabular}

\section{Analysis Data Method}

The data obtained will then processed using a computer program tool (microsoft excel) and analyzed as follows: 


\section{Markowitz Model}

The Markowitz model is calculated with the help of Microsoft excel with several stages of data calculation and the following steps are carried out;

1. Calculating the expected return of each investment instrument.

The following is the formula for finding the expected return value::

$$
E\left(R_{i}\right)=\frac{\sum_{t=1}^{N} R_{i t}}{N}
$$

2. Calculating the standard deviation of each investment instrument.

$$
\sigma_{i}^{2}=\frac{\sum_{j=1}^{N}\left[R_{i j}-E\left(R_{i}\right)\right]^{2}}{N}
$$

3. Calculate the variance of each investment instrument.

The following is the formula for finding the value of variance:

$$
\sigma_{p}^{2}=\sum_{i=1}^{n} \sum_{j=1}^{n} w_{i} \cdot w_{j} \cdot \sigma_{i j}
$$

4. Calculating the covariance value between stocks in the portfolio

$$
C V_{i}=\frac{\sigma_{i}}{E\left(R_{i}\right)}
$$

5. Calculating the proportion of Optimal stock investment (Wi) based on investor preferences

$$
W_{i}=\frac{100 \%}{n}
$$

6. Create an investment instrument variance-covariance matrix

$$
\left(\begin{array}{cccc}
\sigma_{11} \sigma_{12} \sigma_{13} & \ldots & \sigma_{1 n} \\
\sigma_{21} \sigma_{22} \sigma_{23} & \ldots & \sigma_{2 n} \\
\sigma_{31} \sigma_{32} \sigma_{33} & \ldots & \sigma_{3 n} \\
\sigma_{n 2} \sigma_{n 3} & \ldots & \sigma_{n n}
\end{array}\right)
$$

7. Calculating Portfolio Expected Return

$$
E\left(R_{p}\right)=\sum_{i=1}^{n} X_{i} E\left(R_{i}\right)
$$

Where:

$\mathrm{E}(\mathrm{Rp})=$ Expected return from portfolio

$\mathrm{Wi}=$ Position of the $\mathrm{i}$-th investment against all investment instruments in the portfolio

$\mathrm{E}(\mathrm{R} i)=$ Expected return of the $\mathrm{i}$-th investment instrument

$\mathrm{N}=$ the number of data observations

8. Calculating the Porfolio Variance

With the formula:

$$
\sigma_{p}^{2}=\sum_{i=1}^{n} \sum_{j=1}^{n} w_{i} \cdot w_{j} \cdot \sigma_{i j}
$$

Where:

$\sigma_{p}^{2}=$ portfolio variance

$\mathrm{Wi}=$ Position of the i-th investment against all investment instruments in the portfolio. 
As stated by Sinha and Tripathi (2017) after connecting the return and risk values between portfolio instruments, if there is a portfolio instrument with a negative correlation, then the negatively correlated portfolio instrument becomes a reference. A negative correlation indicates the opposite trend to its counterpart. Portfolio instruments that have contradictory correlation values must be included in the portfolio pool, because it is a good opportunity, regardless of whether the market will give a positive or negative sentiment. The negatively correlated portfolio instruments will compensate each other's risk.

9. Calculate portfolio covariance

$$
C V_{p}=\frac{\sigma_{p}}{E\left(R_{p}\right)}
$$

Furthermore, all portfolio instruments are ranked based on return, risk, and return/risk (return divided by risk), so that a rating of the proportion of investment instruments will be obtained based on the highest return with the lowest risk.

\section{Sharpe Model}

The Sharpe ratio is measured by comparing the portfolio risk premium with the portfolio risk expressed by the standard deviation. As follows:

$$
S=\frac{R p-R f}{\sigma p}
$$

Where:

$$
\begin{aligned}
& \mathrm{S}=\text { Sharpe Ratio } \\
& \mathrm{Rp}=\text { Return portfolio or portfolio return, i.e. the average rate of return (return) } \\
& \mathrm{Rf}=\text { Risk free rate is the risk-free interest rate. The } \mathrm{Rf} \text { rate in this study used the annual BI rate } \\
& \sigma p=\text { Portfolio risk (annual), or the standard deviation of the range between portfolio return data. }
\end{aligned}
$$

The interpretation of the Sharpe ratio is, by comparing with Rf. Sharpe Ratio value > Rf rate, it means that the investment in the portfolio instrument is good. The greater the sharpe ratio value compared to $\mathrm{R}$, the better, because the moving average yield is greater than the risk free rate.

\section{Different Test (t-Test)}

In an effort to find out whether there is a significant difference between the results of the calculation of the Markowitz model and the results of the calculation of the Sharpe ratio, a different test was carried out. The difference test in this study used an independent sample T-test. The purpose of the t-test is to compare the mean of unrelated (unpaired) groups with one another. Do the two groups have the same average value or are they not significantly the same (Ghazali, 2011).

The independent t-sample test has a significance level of 5\%, which means that decision making in rejecting the correct hypothesis is a maximum of 5\%. Decision making is done by comparing the value of $t$ count with the value of $\mathrm{t}$ table:

If the value of $t$ count $>$ the value of $t$ table then $\mathrm{H}_{0}$ is accepted.

If the value of $t$ count < value of $t$ table then $\mathrm{H}_{0}$ is rejected.

Analysis of decision making other than using $\mathrm{t}$ count and $\mathrm{t}$ table can be analyzed by looking at the probability value.

If the probability of significance $<0.05$ then $\mathrm{H}_{0}$ is accepted

If the significance probability $>0.05$ then $\mathrm{H}_{0}$ is rejected.

\section{Correlation Analysis}

Correlation analysis is a statistical technique used to analyze the relationship between two or more quantitative variables. Partial correlation analysis was used to determine the strength of the relationship or correlation between the independent and dependent variables. Measurement of the closeness of the relationship between the independent and dependent variables used Product moment correlation (Pearson) to test the associative relationship or if the data is in the form of intervals or ratios (Sugiyono, 2010:212). 


\section{Discussion}

\subsection{Markowitz Model Optimal Portfolio}

In analyzing the optimal portfolio with the Markowitz model, it is done by looking for the expected return value of each instrument, then looking for the level of risk through the standard deviation, the difference in this value then becomes the optimum portfolio value, then to determine the optimum instrument composition with the Markowitz model, the covariance and correlation values are needed foreach instrument.

Table 2 presents the individual return of each investment for the average nine investment instruments (securities) for the 2010-2018 period.

Table 2. Individual Return (in \%)

\begin{tabular}{ccccccccccc}
\hline & \multicolumn{1}{c}{} & \multicolumn{3}{c}{ Investment Instruments } & & & \\
\cline { 2 - 11 } Years & $\begin{array}{c}\text { Govern } \\
\text { ment } \\
\text { Securities }\end{array}$ & $\begin{array}{c}\text { Deposit } \\
\text { On Call }\end{array}$ & $\begin{array}{c}\text { Time } \\
\text { Deposit }\end{array}$ & Stock & Bond & Sukuk & $\begin{array}{c}\text { Mutual } \\
\text { Fund }\end{array}$ & $\begin{array}{c}\text { Direct } \\
\text { Placement }\end{array}$ & $\begin{array}{c}\text { Land and } \\
\text { Building }\end{array}$ & $\begin{array}{c}\text { Port- } \\
\text { folio }\end{array}$ \\
\hline 2010 & 11,45 & 4,48 & 9,66 & 3,36 & 12,46 & 4,57 & 0,82 & 23,27 & 16,29 & 9,60 \\
\hline 2011 & 11,11 & 3,35 & 6,73 & 2,47 & 12,46 & 21,52 & 0,42 & 29,50 & 17,84 & 11,71 \\
\hline 2012 & 8,24 & 3,96 & 7,36 & 2,46 & 10,70 & 21,20 & 0,64 & 27,59 & 18,83 & 11,22 \\
\hline 2013 & 9,17 & 14,09 & 7,40 & 2,18 & 10,03 & 7,69 & 0,02 & 7,39 & 18,75 & 8,53 \\
\hline 2014 & 9,57 & 6,80 & 10,96 & 2,37 & 10,25 & 0,00 & 0,00 & 4,10 & 14,55 & 6,51 \\
\hline 2015 & 9,28 & 5,07 & 9,84 & 2,05 & 9,85 & 0,00 & 0,18 & 0 & 14,26 & 5,61 \\
\hline 2016 & 9,00 & 3,00 & 9,17 & 2,22 & 9,85 & 0,00 & 0,33 & 1,48 & 13,55 & 5,40 \\
\hline 2017 & 9,01 & 4,91 & 8,53 & 2,33 & 9,75 & 9,54 & 0,74 & 0,97 & 14,37 & 6,69 \\
\hline 2018 & 8,78 & 3,33 & 9,29 & 2,54 & 9,56 & 8,51 & 0,80 & 2,18 & 16,15 & 6,79 \\
\hline average & $\mathbf{9 , 5 1}$ & $\mathbf{5 , 4 4}$ & $\mathbf{8 , 7 7}$ & $\mathbf{2 , 4 4}$ & $\mathbf{1 0 , 5 5}$ & $\mathbf{8 , 1 1}$ & $\mathbf{0 , 4 4}$ & $\mathbf{1 0 , 7 2}$ & $\mathbf{1 6 , 0 7}$ & 8,01 \\
\hline
\end{tabular}

Sources: Processed Data 2020

The second step after knowing the return of each instrument is to find the expected return. Expected return explains that the level of expected profit is expected from each investment instrument for making investment decisions in the future. With the method (mean method), the expected return value of Pension funds is obtained which is presented in Table 3. Portfolios that have positive expected returns will be optimal portfolio candidates. The portfolios that have the highest average expected return in the top three are Land and Buildings, Direct Placements and Bonds.

Table 3. Expectation return

Source: Processed Data, 2020

\begin{tabular}{lcrr}
\hline \multicolumn{1}{c}{ Portfolio } & R it & e(ri_) & E(ri) \% \\
\hline Government Securities & 0,86 & 0,10 & 9,51 \\
\hline Deposit On Call & 0,49 & 0,05 & 5,44 \\
\hline Time Deposit & 0,79 & 0,09 & 8,77 \\
\hline Stock & 0,22 & 0,02 & 2,44 \\
\hline Bond & 0,95 & 0,11 & 10,55 \\
\hline Sukuk & 0,73 & 0,08 & 8,11 \\
\hline Mutual Fund & 0,04 & 0,01 & 0,44 \\
\hline Direct Placement & 0,96 & 0,11 & 10,72 \\
\hline Land and Buiding & 1,45 & 0,16 & 16,07 \\
\hline
\end{tabular}


Meanwhile, the lowest expected return averages are Mutual Funds, Stocks and Deposits on Call.

A portfolio that has a positive expected return will be an optimal portfolio candidate. The portfolios that have the highest average expected return in the top three are Land and Buildings, Direct Placements and Bonds. Meanwhile, the lowest expected return averages are Mutual Funds, Stocks and Deposits on Call.

The third next step is to calculate the risk of each investment instrument. The investment risk of each investment instrument is calculated based on the standard deviation. Table 4 presents the results of the standard deviation of each investment instrument.

Based on the table, it can be seen that the three portfolios that have the highest risk are Direct Placements with a standard deviation of 11,632, then Sukuk at 7,913 and Deposits on call of 3,250. Meanwhile, the three portfolios with the lowest risk are Mutual Funds with a value of 0.307, followed by Government Securities with a value of 1.009 , then Bonds with a value of 1.070 .

Table 4. Deviation Standard

Source: Processed Data, 2020

\begin{tabular}{lc}
\hline \multicolumn{1}{c}{ Portfolio } & $\begin{array}{c}\text { Deviation } \\
\text { Standard }\end{array}$ \\
\hline Government Securities & 1,009 \\
\hline Deposit On Call & 3,250 \\
\hline Time Deposit & 1,302 \\
\hline Stock & 0,357 \\
\hline Bond & 1,070 \\
\hline Sukuk & 7,913 \\
\hline Mutual Fund & 0,307 \\
\hline Direct Placement & 11,632 \\
\hline Land and Building & 1,909 \\
\hline
\end{tabular}

The fourth step after getting the standard deviation value or risk level of each instrument, is to find the covariance value and correlation between portfolios. Covariance is a measure that shows the direction of movement of two variables. Covariance and correlation between investment instruments is calculated using Microsoft excel. The following is the explanation in Table 5 which presents the results of the covariance and Table 6 which will present the results of the instrument correlation.

The next step is to calculate the most optimal portfolio performance between 2010 and 2018, where the expected return and standard deviation values are set aside to get the Markowitz Model Ratio.

Table 5. Covariance investment instrument

\begin{tabular}{lccccccccc}
\hline $\begin{array}{l}\text { Investment } \\
\text { Instrument }\end{array}$ & $\begin{array}{c}\text { Government } \\
\text { Securities }\end{array}$ & $\begin{array}{c}\text { Deposit On } \\
\text { Call }\end{array}$ & $\begin{array}{c}\text { Time } \\
\text { Deposito }\end{array}$ & Stock & Bond & Sukuk & $\begin{array}{c}\text { Mutual } \\
\text { Fund }\end{array}$ & $\begin{array}{c}\text { Direct } \\
\text { Placement }\end{array}$ & $\begin{array}{c}\text { Land and } \\
\text { Building }\end{array}$ \\
\hline $\begin{array}{l}\text { Government } \\
\text { Securities }\end{array}$ & 1,0181 & 0,3384 & 0,0170 & 0,2319 & 0,9322 & 0,2895 & 0,0286 & 5,7791 & 0,1384 \\
\hline $\begin{array}{l}\text { Deposit On } \\
\text { Call }\end{array}$ & $-0,3384$ & 10,5634 & $-0,6307$ & $-0,3069$ & $-0,7226$ & $-4,168$ & $-0,5933$ & $-7,1796$ & 2,2929 \\
\hline $\begin{array}{l}\text { Time } \\
\text { Deposit }\end{array}$ & 0,0170 & $-0,6307$ & 1,6944 & 0,0545 & $-0,4102$ & $-8,694$ & $-0,0565$ & $-8,6781$ & $-1,8644$ \\
\hline Stock & 0,2319 & $-0,3069$ & 0,0545 & 0,1277 & 0,2678 & 0,3345 & 0,0684 & 2,2706 & 0,1356 \\
\hline Bond & 0,9322 & $-0,7226$ & $-0,4102$ & 0,2678 & 1,1447 & 3,6964 & 0,0799 & 10,7052 & 0,8421 \\
\hline Sukuk & 0,2895 & $-4,1681$ & $-8,6937$ & 0,3345 & 3,6964 & 62,615 & 0,9244 & 69,7703 & 11,4446 \\
\hline
\end{tabular}




\begin{tabular}{lccccccccc}
\hline Mutual Fund & 0,0286 & $-0,5933$ & $-0,0565$ & 0,0684 & 0,0799 & 0,9244 & 0,0941 & 1,0882 & 0,0468 \\
\hline $\begin{array}{l}\text { Direct } \\
\text { Placement }\end{array}$ & 5,7791 & $-7,1796$ & $-8,6781$ & 2,2706 & 10,7052 & 69,770 & 1,0882 & 135,3087 & 15,8139 \\
\hline $\begin{array}{l}\text { Land and } \\
\text { Building }\end{array}$ & 0,1384 & 2,2929 & $-1,8644$ & 0,1356 & 0,8421 & 11,445 & 0,0468 & 15,8139 & 3,6448 \\
\hline
\end{tabular}

Source: Processed Data, 2020

Table 6. Correlation Investment Instrument

\begin{tabular}{|c|c|c|c|c|c|c|c|c|c|}
\hline $\begin{array}{l}\text { Investment } \\
\text { Instrument }\end{array}$ & $\begin{array}{c}\text { Government } \\
\text { Securities }\end{array}$ & $\begin{array}{l}\text { Deposio } \\
\text { On Call }\end{array}$ & $\begin{array}{c}\text { Time } \\
\text { Deposito }\end{array}$ & Stock & Bond & Sukuk & $\begin{array}{c}\text { Mutual } \\
\text { Fund }\end{array}$ & $\begin{array}{c}\text { Direct } \\
\text { Placement }\end{array}$ & $\begin{array}{c}\text { Land } \\
\text { and } \\
\text { Building }\end{array}$ \\
\hline $\begin{array}{l}\text { Government } \\
\text { Securities }\end{array}$ & 1,0000 & & & & & & & & \\
\hline $\begin{array}{l}\text { Deposit On } \\
\text { Call }\end{array}$ & $-0,1032$ & 1,0000 & & & & & & & \\
\hline Time Deposit & 0,0130 & $-0,1491$ & 1,0000 & & & & & & \\
\hline Stock & 0,6430 & $-0,2642$ & 0,1172 & 1,0000 & & & & & \\
\hline Bond & 0,8635 & $-0,2078$ & $-0,2945$ & 0,7005 & 1,0000 & & & & \\
\hline Sukuk & 0,0363 & $-0,1621$ & $-0,8440$ & 0,1183 & 0,4366 & 1,0000 & & & \\
\hline Mutual Fund & 0,0925 & $-0,5951$ & $-0,1414$ & 0,6240 & 0,2433 & 0,3808 & 1,0000 & & \\
\hline $\begin{array}{l}\text { Direct } \\
\text { Placement }\end{array}$ & 0,4924 & $-0,1899$ & $-0,5731$ & 0,5462 & 0,8602 & 0,7580 & 0,3050 & 1,0000 & \\
\hline $\begin{array}{l}\text { Land and } \\
\text { Building }\end{array}$ & 0,0719 & 0,3695 & $-0,7502$ & 0,1988 & 0,4123 & 0,7576 & 0,0800 & 0,7121 & 1,0000 \\
\hline
\end{tabular}

Source: Processed Data, 2020

The following are the results of the calculations presented in Table 7.

Based on Table 7 presented, it can be concluded that the overall portfolio from 2010 to 2018, it achieved the best or most optimal performance in 2013 with a Markowitz Ratio of 3.21\% and the lowest was in 2015 with a Markowitz Ratio of 0.56 . \%. Next is to determine the optimal portfolio based on investor preferences. Based on the assumption that investor preferences are only based on the expected return and risk from the portfolio, the implication is that investors have the same utility function, in reality each investor has different utilities. If investors' preferences for portfolios are different because they have different utility functions, the optimal portfolio for each investor will be different.

Table 7. Efficient Portfolio Markowitz Model

\begin{tabular}{cccc}
\hline Years & $\begin{array}{c}\text { Expectation } \\
\text { Return }\end{array}$ & $\begin{array}{c}\text { Deviation } \\
\text { Standard }\end{array}$ & Markowitz Ratio \\
\hline 2010 & 9,596 & 6,757 & 2,84 \\
\hline 2011 & 11,711 & 9,183 & 2,53 \\
\hline 2012 & 11,220 & 8,762 & 2,46 \\
\hline 2013 & 8,526 & 5,312 & 3,21 \\
\hline 2014 & 6,512 & 4,896 & 1,62 \\
\hline 2015 & 5,612 & 5,049 & 0,56 \\
\hline 2016 & 5,400 & 4,709 & 0,69 \\
\hline 2017 & 6,685 & 4,416 & 2,27 \\
\hline 2018 & 6,792 & 4,662 & 2,13 \\
\hline
\end{tabular}

Source: Process Data, 2020 
The Markowitz model can provide information from the portfolio value with the smallest risk for a certain expected return. Or the possibility of investors preferring a greater risk with a higher expected return compensation as well.

\section{Optimal portfolio selection is based on risk takers.}

In determining the risk taken for investors who like risk, the highest standard deviation value is chosen from the nine available portfolios, therefore the calculated risk is 11,632 with a return obtained of 1,762. Here is the optimal proportion based on risk-taker investors.

The results of calculations using the Excel program are presented in Table 8 and the bar graph for the positive proportion value is in Figure 2.

Table 8. Optimal proportions based on risk taker

\begin{tabular}{|c|c|c|c|}
\hline Portfolio & Proportion & $\%$ & Positive Value \\
\hline Government Securities & 38,465 & & 32,50 \\
\hline Deposit On Call & 2,968 & & 2,51 \\
\hline Time Deposit & 21,587 & & 18,24 \\
\hline Stock & $-48,631$ & & - \\
\hline Bond & 28,486 & & 24,07 \\
\hline Sukuk & 2,106 & & 1,78 \\
\hline Mutual Fund & $-66,963$ & & - \\
\hline Direct Placement & $-1,751$ & & - \\
\hline Land and Building & 24,732 & & 20,90 \\
\hline Total & 1,000 & & 100,00 \\
\hline
\end{tabular}

Source: Process Data, 2020

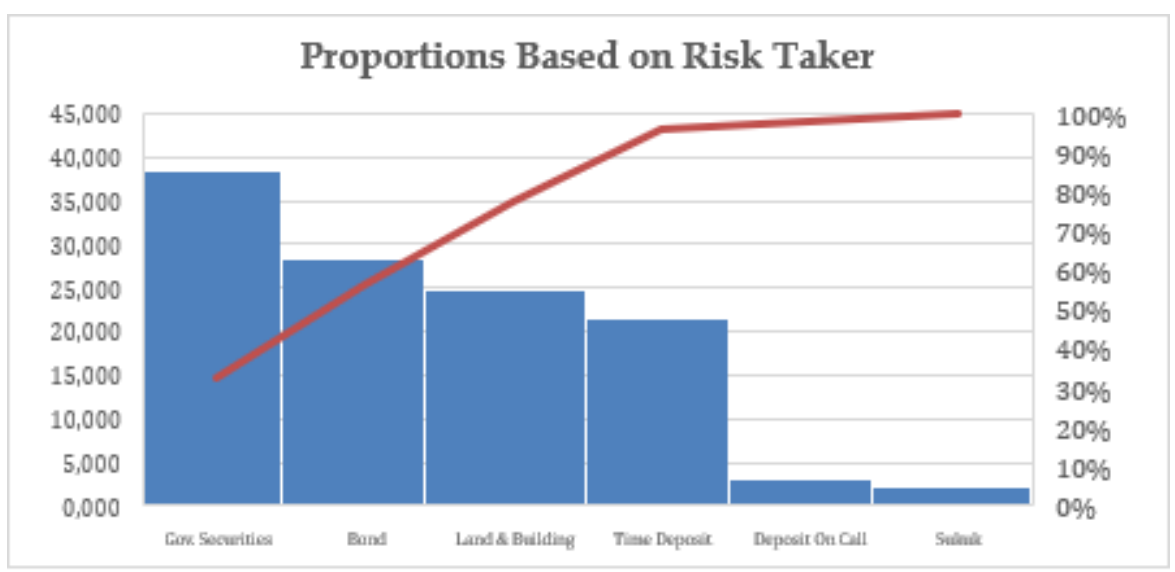

Figure 2. Optimal Proportion Based on Risk Taker

\section{Optimal portfolio selection based on risk neutrality investors}

The second type of investor is an investor in the middle where a neutral investor who does not really like high or low risk is called a neutral investor. Risk-neutral investors will demand increases at the same rate of increase in return for each increase in risk. In this study, the determination of the risk taken for investors who like neutral risk is chosen by the middle standard deviation of the nine available portfolios. 
Table 9. Optimal Proportions based on risk nautrality

\begin{tabular}{|c|c|c|}
\hline Portfolio & Proportion & \% Positive Value \\
\hline Government Securities & 10,57 & 32,59 \\
\hline Deposit On Call & 0,82 & 2,52 \\
\hline Time Deposit & 5,94 & 18,32 \\
\hline Stock & $-12,98$ & - \\
\hline Bond & 7,73 & 23,84 \\
\hline Sukuk & 0,58 & 1,79 \\
\hline Mutual Fund & $-17,97$ & - \\
\hline Direct Placement & $-0,49$ & - \\
\hline Land and Building & 6,79 & 20,94 \\
\hline Total & 1,000 & 100,00 \\
\hline
\end{tabular}

Source: Process Data, 2020

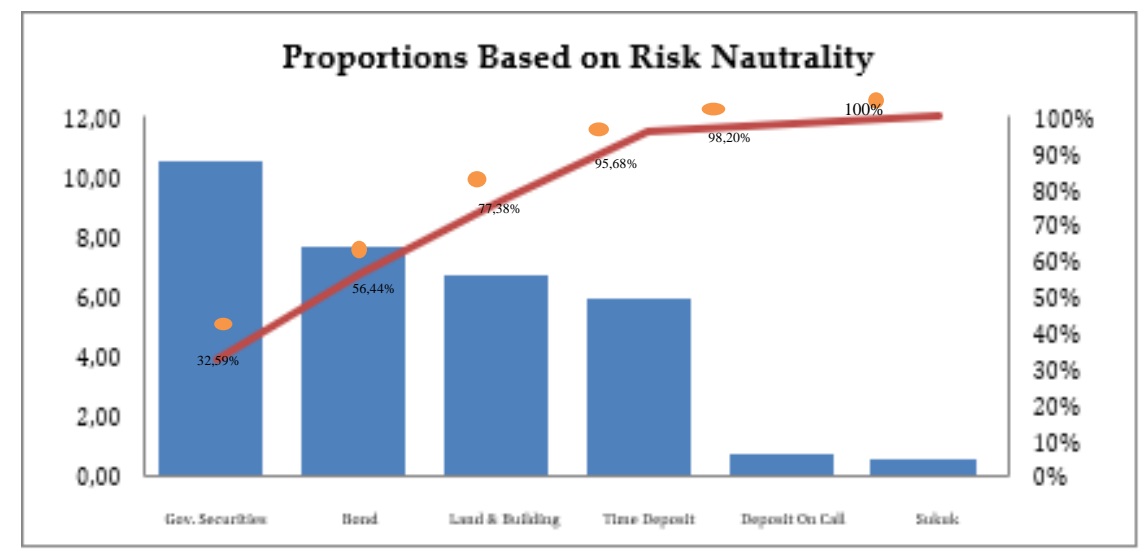

Figure 3. Optimal Proportion Based on Rist Nautrality

The results of the calculation, the selected risk level is 3.194 with a return of 0.496 .With the help of the Excel program, the calculation results are presented in Table 9 and the bar graph for the positive proportion value is in Figure 3.

In this study, investors have a risk level of 3.194 and generate an expected return of 0.496. At this neutral risk, investors have a small positive rate of return and tend to be negative, therefore it is better for investors who are in a neutral position to allocate investment funds with a proportion with a positive value according to table 4.8 with the largest proportion in the portfolio in state securities..

\section{Optimal portfolio selection based on risk averse investors (risk averter)}

In determining the risk taken for investors who do not like risk, the standard deviation value is chosen from the mvp (minimum variance portfolio) of the nine available portfolios, and with the help of the Excel Solver program, the mvp number is 0.2677 which is a calculated risk with a return of 0.019 . The following calculation results are presented in Table 10 and the bar graph of the positive proportion value in Figure 4.

Based on the help of the excel solver program, with an mvp value of 0.2677 , the optimal portfolio formed is the same as the two types above, where the investment instrument with the same positive value and the same negative one, only the proportions are different. And to decide to take a low risk, investors can choose investments that do not generate negative values, and can allocate the largest proportion of investment funds to the Government Securities portfolio. 
Table 10. Optimum proportions based on risk averter

\begin{tabular}{|c|c|c|}
\hline Portfolio & Proportion & \% Positive Value \\
\hline Government Securities & 0,893 & 33,92 \\
\hline Deposit On Call & 0,072 & 2,73 \\
\hline Time Deposit & 0,507 & 19,26 \\
\hline Stock & $-0,616$ & - \\
\hline Bond & 0,537 & 20,39 \\
\hline Sukuk & 0,055 & 2,09 \\
\hline Mutual Fund & $-0,971$ & - \\
\hline Direct Placement & $-0,047$ & - \\
\hline Land and Building & 0,569 & 21,61 \\
\hline Total & 1,000 & 100,00 \\
\hline
\end{tabular}

Source: Process Data, 2020

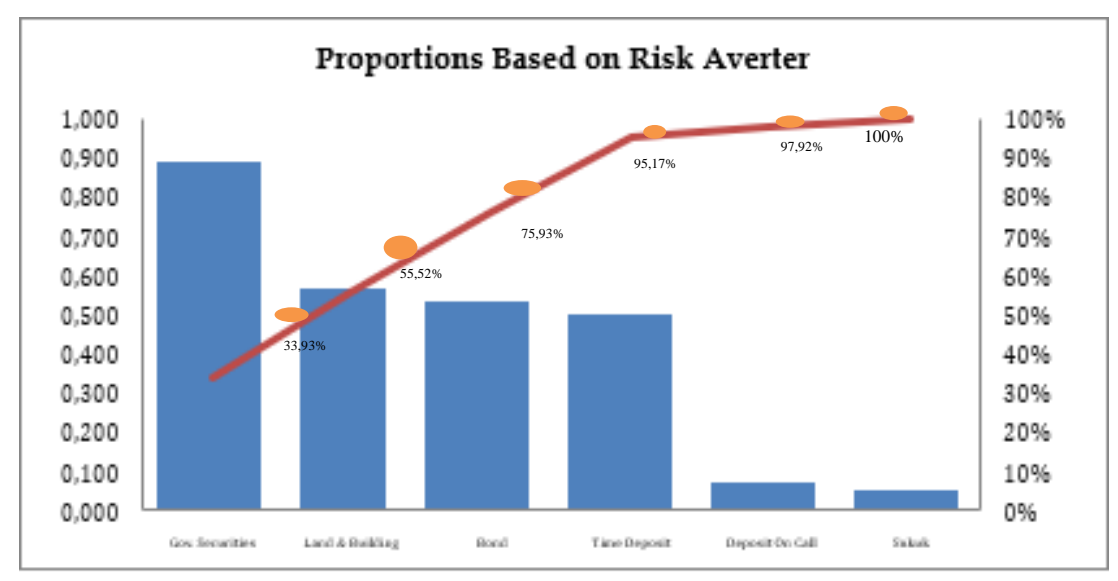

Figure 4. Optimal Proportion Based on Risk Averter

\section{Optimal Portfolio with Sharpe Model}

The first step taken to find the sharpe ratio value is to calculate the average value of the combined portfolio from 2010 to 2018 as was done in the steps for calculating the optimal portfolio of the Markowitz model, then calculate the risk free value based on the BI interest reference from 2010 to 2018 (source: bps.go.id/linkTableDinamis/view/id/ 1061) as well as the standard deviation of each year of research with different results (Table 4), the calculation of the Sharpe ratio can be seen in Table 11.

Table 11. Sharpe Ratio

\begin{tabular}{ccccc}
\hline Years & $\begin{array}{c}\text { Average } \\
\text { Return }\end{array}$ & Risk Free & $\begin{array}{c}\text { Deviation } \\
\text { Standard }\end{array}$ & Sharpe Ratio \\
\hline 2010 & 9,596 & 6,5 & 6,757 & 45,819 \\
\hline 2011 & 11,711 & 6,0 & 9,181 & 62,195 \\
\hline 2012 & 11,220 & 5,75 & 8,762 & 62,431 \\
\hline 2013 & 8,526 & 7,5 & 5,312 & 19,311 \\
\hline 2014 & 6,512 & 7,75 & 4,896 & $-25,278$ \\
\hline 2015 & 5,612 & 7,5 & 5,049 & $-37,383$ \\
\hline 2016 & 5,400 & 4,75 & 4,709 & 13,810 \\
\hline 2017 & 6,685 & 4,25 & 4,416 & 55,141 \\
\hline 2018 & 6,792 & 5,5 & 4,662 & 27,701 \\
\hline
\end{tabular}

Source: Process Data, 2020 
Based on Table 11, it can be seen that the highest sharpe value was the portfolio in 2012 of $62.43 \%$ while the lowest sharpe value was the portfolio in 2015 of $-37.3827 \%$. This means that from the dive portfolio in 2010 to 2018, the best performance was the portfolio in 2012 and the worst performance was the portfolio in 2015.

After knowing the portfolio performance during 2010 to 2018, then the formation of the optimal portfolio with the Sharpe model is arranged, in the process of forming the optimal portfolio to find out the best instrument composition to achieve maximum return, for that the risk free rate of $6.17 \%$ is still calculated. The following are the results of the optimal proportion of the PLN Pension Fund investment portfolio as presented in Table 12 and Figure 5 .

Table 12. Optimal Proportion Sharpe Model

\begin{tabular}{lcc}
\multicolumn{1}{c}{ Portfolio } & Proporsi & $\begin{array}{c}\text { \% Positive } \\
\text { Value }\end{array}$ \\
\hline \multicolumn{1}{c}{ Government Securities } & 297,53 & 32,90 \\
\hline Deposit On Call & 23,29 & 2,57 \\
\hline Time Deposit & 167,48 & 18,52 \\
\hline Stock & $-327,64$ & - \\
\hline Bond & 208,60 & 23,06 \\
\hline Sukuk & 16,84 & 1,86 \\
\hline Mutual Fund & $-462,72$ & - \\
\hline Direct Placement & $-14,11$ & - \\
\hline Land and Building & 190,75 & 21,09 \\
\hline Total & 1,000 & 100,00 \\
\hline
\end{tabular}

Source: Process Data, $2 \longdiv { 0 2 0 }$

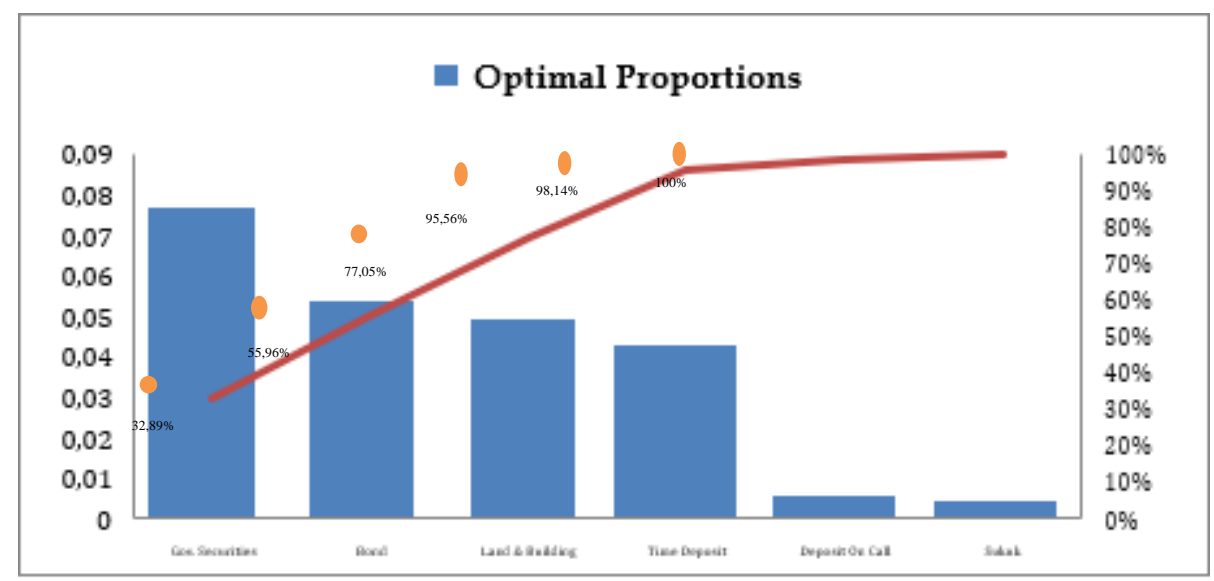

Figure 5. Optimal Proportion Sharpe Model

For other instruments that have a negative value, if selected above the required minimum, it is possible that based on the Sharpe model, it will result in a decrease in portfolio returns and can result in losses.

\section{Correlation Test}

The results of the correlation test between the results of the optimization of the Makowiz and Sharpe models with the three performance indicators of the PLN Pension Fund by using the Pearson Correlation test, are presented in Table 13 . 
Table 13. Correlation financial performance among Markowitz Model and Sharpe Model

\begin{tabular}{ccccc}
\hline \multirow{2}{*}{ Financial Indicators } & \multicolumn{2}{c}{ Markowitz Model } & \multicolumn{2}{c}{ Sharpe Model } \\
\cline { 2 - 5 } & Coefficient & Interpretation & Coefficient & Interpretation \\
\hline ROI & 0,243 & Weak & 0,439 & Medium \\
\hline FAR/RKD & 0,637 & Strong & 0,379 & Weak \\
\hline ROA & 0,281 & Weak & 0,460 & Medium \\
\hline
\end{tabular}

Source: Output of Pearson Correlation test, 2020.

\section{Different Test (t-Test)}

The difference test in this study aims to test the hypothesis whether there is a difference between the Markowitz and Sharpe analysis models. In this study, a different test was carried out using a parametric statistical test, namely the paired sample t-test. The results obtained from the Paired Sample

T-test as listed in Table 14.

Based on the results of the sample paired t-test output, obtained a significance value of 0.094 , the value is greater than 0.05 so it can be concluded that there is no difference in the analysis of the Markowitz and Sharpe models on the measurement of portfolio performance optimization.

Table 14. Paired Sample T-test

\begin{tabular}{|c|c|c|c|c|c|c|c|c|c|}
\hline & & \multicolumn{2}{|c|}{ Mean } & $\mathrm{N}$ & \multicolumn{2}{|c|}{ Std. Deviation } & \multicolumn{3}{|c|}{ Std. Error Mean } \\
\hline \multirow[t]{7}{*}{ Pair 1} & Markowitz & & 2,0343 & & 9 & ,91291 & & & ,30430 \\
\hline & Sharpe & & 24,8608 & & 9 & 36,59009 & & & 12,19670 \\
\hline & & \multicolumn{5}{|c|}{ Paired Differences } & \multirow[b]{5}{*}{$\mathrm{T}$} & \multirow[b]{5}{*}{$\mathrm{df}$} & \multirow{5}{*}{$\begin{array}{c}\text { Sig. } \\
\text { (2-tailed) }\end{array}$} \\
\hline & & \multicolumn{5}{|c|}{ 95\% Confidence } & & & \\
\hline & & \multirow[b]{3}{*}{ Mean } & \multirow{3}{*}{$\begin{array}{c}\text { Std. } \\
\text { Deviation }\end{array}$} & Std. & \multirow{2}{*}{\multicolumn{2}{|c|}{$\begin{array}{c}\text { Interval of the } \\
\text { Difference }\end{array}$}} & & & \\
\hline & & & & Error & & & & & \\
\hline & & & & Mean & Lower & Upper & & & \\
\hline Pair 1 & $\begin{array}{l}\text { Markowitz } \\
\text { - Sharpe }\end{array}$ & $-22,82644$ & 35,98365 & 11,99455 & $-50,48593$ & 4,83304 & $-1,903$ & 8 & ,094 \\
\hline
\end{tabular}

Source: Output of SPSS, 2021.

\section{Conclusions, Implications, Suggestions and Limitations}

\subsection{Conclusions}

a. In the Markowitz model, the performance of the pension fund portfolio achieved the best performance in 2013 while the worst occurred in 2015 , and to achieve a more efficient portfolio in the future, the best composition is to allocate more of the portfolio in succession to Government Securities, Bonds, Land and Buildings, Time Deposits, On Call Deposits and Sukuk. Previous researchers who have also analyzed the Markowitz model include: In previous studies, many other researchers have also calculated the optimal portfolio with the Markowitz model, including (Natalia, 2014) (Pracanda \& Abundanti, 2017) (Eka Pratiwi et al., 2014) (Chandra, 2014). \& Hapsari, 2014)(Mahayani \& Suarjaya, 2019) (Krisnawan, 2019)

b. In the Sharpe model, the performance of PLN's pension fund portfolio achieved the best performance in 2012 while the worst occurred in 2015 , and to achieve a more efficient portfolio in the future, the best composition is to allocate more portfolio instruments in succession to Government Securities, Bonds, Land and Buildings, Time Deposits, On Call Deposits and Sukuk. In previous studies, many other researchers have also calculated the optimal portfolio with the Sharpe model, among others (Hardjopranoto, 2020) (Susilowati et al., 2020) (Iskandar et al., 2020) 
c. There is no significant difference between the Markowitz analysis model and the Sharpe model on the measurement of optimizing the performance of the PLN Pension Fund portfolio.

d. By taking into account investors' preferences for risk in the analysis of investment optimization, the Markowitz model with a preference that is neutral on risk, is suitable for use by the PLN Pension Fund in analyzing its investment portfolio diversification as well as being the basis for making investment decisions in the future.

\subsection{Implication}

For the management of pension funds, especially for investment managers, various calculation methods can be used to assess the optimization of investment diversification in order to produce the maximum return value and can calculate risk so that the investment continues to produce the required profit so that it is more accurate and targeted in determining the type of investment.

\subsection{Suggestions}

Pension fund manager PT. PLN can take the results of this study as a professional consideration in placing their investment funds. Based on the results of this study, the portfolio model that tends to be suitable for use by PT PLN pension fund managers is the Markowitz model with a risk-neutral preference in securing and optimizing the placement of its investment funds.

\subsection{Limitations}

The weakness in this study is the optimization test only uses two methods, besides that in this study it does not compare the optimization between pension fund managers with one another, both similar and dissimilar.

\section{References}

Iskandar, D., Martalena, M., \& Julianto, N. D. (2020). Perbandingan Kinerja Portofolio yang Dibentuk dengan Single Index Model pada Saham-Saham yang Terdaftar dalam Indeks LQ45 dan Kompas 100 Tahun 2018. Jurnal Akuntansi Maranatha. https://doi.org/10.28932/jam.v12i1.2041

Iwan Firdaus, \& Sri Anah dam Fitri Nadira. (2018). Analisis Pembentukan Portofolio Optimal Menggunakan Model Indeks Tunggal (Studi kasus: Saham LQ45 Yang terdaftar di BEI Tahun 2012-2016). Jurnal Ekonomi, XXIII(2), 203-225.

Jogiyanto Hartono. (2016). Teori Portofolio Dan Analisis Investasi (Edisi 10). BPFE: Jogjakarta.

Krisnawan, O. O. B. (2019). Optimalisasi portofolio investasi program tunjangan hari tua (THT) pada PT Taspen (persero). Indonesian Treasury Review Jurnal Perbendaharaan Keuangan Negara Dan Kebijakan Publik. https://doi.org/10.33105/itrev.v4i1.117

Lembar Negara Republik Indonesia Tahun 1992 Nomor 37, Undang-undang Nomor 11 tahun 1992 tentang Dana Pensiun.

Mahayani, N. P. M., \& Suarjaya, A. A. G. (2019). Penentuan Portofolio Optimal Berdasarkan Model Markowitz Pada Perusahaan Infrastruktur Di Bursa Efek Indonesia. E-Jurnal Manajemen Universitas Udayana. https://doi.org/10.24843/ejmunud.2019.v08.i05.p17

Natalia, E. (2014). Penentuan Portofolio Saham Yang Optimal Dengan Model Markowitz Sebagai Dasar Penetapan Investasi Saham (Studi pada Perusahaan Food and Beverage yang Terdaftar di Bursa Efek Indonesia Tahun 2012). Jurnal Administrasi Bisnis S1 Universitas Brawijaya.

Njeru, S. E., Dominic, N. M., \& Fredrick, K. (2015). Evaluation of Financial Performance on Portofolio Holdings held Pension Funds in Kenya. European Scientific Journal, 11(16), 1857-7881.

Nur Sarva Jayana dan Pardomuan Sihombing. (2019). Optimal Portofolio Analysis of IDX-30 And LQ-45 Portofolio With CAPM Method of The Indonesia Stock Exchange. DIJBM, 1(2), 132-141.

Nurdhiana, E. V. dan N. (2017). Analisis Pembentukan Portofolio Optimal Menggunakan Capital Asset Pricing Model Serta Penilaian Kinerja Portofolio Berdasarkan Metode Shrape Ratio, Treynor Ratio, Dan Jensen. Optimization Portfolio Analysis Using Capital Asset Pricing Model and Performance, 4(1), 95-102.

Pracanda, S., \& Abundanti, N. (2017). Pembentukan Portofolio Optimal Dengan Menggunakan Model Markowitz Pada Saham Indeks Idx30 Di Bursa Efek Indonesia. E-Jurnal Manajemen Universitas Udayana.

Sharpe, Williem Fdkk. (2005). Investasi. Jilid 1, indeks, Jakarta.

Sinha, R., \& Tripathi, P. K. (2017). A Comparison of Markowitz and Sharpe' Model of Portfolio Analysis. IJMBF, $6(1), 18-24$. 
Surya dan Harnovinsyah. (2016). Analisis Pengaruh Arus Kas, Leverage, Tingkat Pertumbuhan, Ukuran Perusahaan Terhadap Kebijakan Dividen Studi Pada Industri Manufaktur yang Tercatat di BEI 2011 - 2013. Jurnal TEKUN, VII(1), 49-61.

Susilowati, D., Juwari, J., \& Noviadinda, C. (2020). Analisis Kinerja Portofolio Saham dengan menggunakan Metode Indeks Sharpe, Treynor dan Jensen pada Kelompok Saham Indeks SRI-KEHATI di Bursa Efek Indonesia. Jurnal GeoEkonomi.

\section{Copyrights}

Copyright for this article is retained by the author(s), with first publication rights granted to the journal.

This is an open-access article distributed under the terms and conditions of the Creative Commons Attribution license (http://creativecommons.org/licenses/by/4.0/). 